\title{
ANALYSIS OF STATIC MORPHOSTRUCTURE CONDITIONS WITH DYNAMIC MORFOSTRUCTURE (LANDSLIDE TYPE)
}

\author{
SUWARNO ${ }^{1}$ (D), MISNAH ${ }^{2}$, MUJIARTO $^{3}$ (D)
}

DOI: 10.21163/GT_2020.151.06

\begin{abstract}
:
Landslides occur in many types of Tuff rocks and Tertiary-aged andesite sandstones which can cause changes in the shape of the earth's surface, which shows the development of dynamic morphostructure. The purpose of this study was to determine the relationship of static morphostructure with dynamic morphostructure landslide type in Pekuncen Banyumas District. The research method used a survey method which included fieldwork (for inventory of static morphostructure and dynamic morphostructure landslide type) and laboratory work (for interpretation of aerial and satellite photo, and analysis of static morphostructure relationships with dynamic morphostructures landslide type). The results of the study found many observable landslides and geological structures. The geological structure that contained are in the structure of folds, fractures, and volumes. There is a relationship between landslide and geological structures. In fault structures, folds and layers sloping with patterns of clustered landslide, while in volcanic structures, the patterns of landslide are spread.
\end{abstract}

Key-words: Static morphostructure, Dynamic morphostructure, Landslide, Indonesia

\section{INTRODUCTION}

Based on the reading of the Geological Map of the Purwokerto and Tegal sheets, on a scale of 1:100,000, Pekuncen District is composed of Tertiary to Holocene rocks and consists of several geological structures. The age of these rocks shows the old one to young, Tertiary rocks are older rocks than the Holocene. Old-aged rocks with intensive weathering levels indicated by the thickness of weathering and more landslide (Suwarno, 2014). In areas with geological structure in form of faults and sloping rock layers which are composed of sedimentary rocks which have undergone weathering and changes in vegetation cover occur, then the area has many landslides (Kevin, et al., 2017; Luigi, et al., 2014). Landslides are a form of the manifestation of dynamic morphostructures, while the appearance of geological structures is an embodiment of active morphostructures (Verstappen, 2014).

Landslides are the results of relationships reciprocal between systems in nature, including geological, geomorphological, hydrological, climate, and land use systems (Irimus et al., 2017; Suwarno et al., 2019). The geological factor in this case is rock and geological structure, while geomorphological factors are slopes (Pacione, 1999). The factors that cause landslides are human activities and physical conditions. Physical conditions include rocks,

\footnotetext{
$1^{*}$ Geography Education Department of Universitas Muhammadiyah Purwokerto, Jl. Raya Dukuh Waluh Kembaran, Purwokerto, Jawa Tengah, Indonesia, ${ }^{*}$ Corresponding author: suwarnohadimulyono@gmail.com

${ }^{2}$ Tadulako University, Jl. Soekarno Hatta Km. 9, Palu, Sulawesi Tengah 94148, Indonesia

${ }^{3 *}$ Universitas Muhammadiyah Tasikmalaya, Jl. Tamansari KM. 2,5, Tasikmalaya 46196, Indonesia,

*Corresponding author: mujiarto@umtas.ac.id
} 
geological structures, and slopes. The human activities influential include cutting slopes for construction road, houses, agriculture and mining of rocks and sand (Sartohadi, 2008).

Knapen et al. (2005) explain that landslides are caused by several factors including slope, rock, soil and land use. Landslides and landslide densities are influenced by factors such as morphology form of land surface, geological conditions, the distance between river channels, earthquakes (Havenith, et al., 2015). Suwarno \& Sutomo (2012) conducted a study in Pekuncen Subdistrict indicating that there were landslides that could still be observed in 98 locations and found several waterfalls and rocks outcrops with sloping layer structures. Landslides occur in many types of tuff rocks and andesite sandstones that are Tertiary. Landslide are influenced by several factors, they are geological factors consisting of material type/rock, major fault distance, rock mass structure, while other factors consist of morphology, elevation, slope angle, slope aspect, avalanche type, soil type, land use and rain (Glenn, et al., 2006; Nadim, et al., 2006; Thapa and Esaki, 2007; Lan, et al., 2004).These landslides can cause changes in the shape of the earth's surface, it means that the area shows the development of dynamic structure morphostructure. The development of the dynamic morphostructures is influenced by the static morphostructures found in the area, therefore an in-depth study of the active and dynamic morphostructure relationships is needed.

\section{METHODS}

\subsection{Materials and Research Tool}

a. The material included:

1) 1: 50,000 in panchromatic aerial photographs of 1: 50,000 in 1994

2) Indonesian topographical maps of Ajibarang sheets, Paguyangan scale of 1:25,000

3) a sheet of geological maps of Purwokerto - Tegal scale of 1: 100,000

4) satellite imagery of Banyumas Regency in 2005

b. Research Tools

5) GPS (global positioning system), used to determine the coordinates of the measuring point.

6) Geological hammer, for identifying the rocks.

7) Geological compass, for measuring dip, strike, and measurement direction.

8) Camera, for making documentation of important phenomena in the field.

9) Mirror stereos, for interpreting of aerial photographs.

10) Meter, for measuring the slope length, depth of weathering rock.

11) Abney level, for measuring the slope.

\subsection{Research Path}

a. Pre-fieldwork.

At this stage doing interpretation of aerial or satellite photos and other material maps in order to compile a map of the temporary used for material reference land field work.

b. Fieldwork

In this field work, it is intended to look for data both primary and secondary data to test the results of interpretations of aerial photographs or from $\mathrm{m}$ aps carried out in the laboratory. The field survey in this case is conducting observations and measurements on geomorphological aspects which include static morphostructures, and dynamic morphostructures. 


\section{c. Laboratory Analysis}

Laboratory analysis is the reinterpretation of aerial and satellite photos, the making of landform maps, static morphostructural maps, and dynamic structure morphostructure maps in the form of landslides.

\subsection{Variables and Data}

\section{a. Variables}

The variables needed in this study include the influence variables namely static morphostructural aspects and the affected variables namely dynamic structure morphostructures. Static morphostructures include geological structures such as folds, fractures or horizontal layers, and dynamic morphostructures structures in the form of landslides and types. Primary data include slope length, slope, slope shape, valley shape, valley width, valley length, rock type, geological structure, weathering depth. Secondary data related to this study include landslide events data, rainfall data and thematic maps.

b. Data acquisition

Data acquisition is a way to obtain data from each variable either directly or indirectly. The way to obtain data on each variable varies, among others, by making observations, measurements in the field or in the laboratory, analyzing thematic maps and secondary data. The following is the method of obtaining the data needed in the study:

1) slope length, obtained from measurements of field

2) slope, obtained from DEM analysis of RBI maps,

3) slope shape, obtained from interpretation of aerial photographs and satellite imagery,

4) valley shape, obtained from interpretation of aerial photographs and imagery Satellites,

5) rock types, obtained from field observations,

6) geological structures, obtained from the interpretation of maps geological and field observations,

7) weathering depths, obtained from field measurements,

8) characteristics of mass movement, obtained from measurements and field observations

9) mass movement events and mass movement types, obtained from secondary data, rainfall data, obtained from secondary data.

\subsection{Analytical approaches}

a. Analysis of Geomorphological aspects consists of static morphostructure, dynamic morphostructure with geomorphological analytical approach presented in the form of static morphostructure maps, and distribution maps of landslide.

$b$. The analysis to determine the relationship between static morphostructure and dynamic morphostructure landslide type using quantitative descriptive by overlaying /overlapping arrangement of static morphostructure maps, and distribution maps of landslide.

\section{RESULTS AND DISCUSSIONS}

\subsection{Research Area Description}

a. Location and wide scale

The study was administratively located in Pekuncen District, Banyumas Regency. The astronomical position of the study area is located between $109^{\circ} 01$ '39 "BT to $109^{\circ} 09^{\prime} 22^{\prime \prime}$ $\mathrm{BT}$ and $7^{\circ} 15^{\prime} 25^{\prime \prime L S}$ to $7^{\circ} 24^{\prime} 37^{\prime \prime} \mathrm{LS}$ or is located between $282,831 \mathrm{mT}$ to $294,317 \mathrm{mT}$ 
and 9,180,805 $\mathrm{mU}$ up to $9,193,344 \mathrm{mU}$ at UTM coordinates. The research area is $8,277.69$ ha, divided into 16 villages, Cibangkong, Petahunan, Semedo, Cikawung, Karangklesem, Candinegara, Cikembulan, Tumiyang, Glempang, Pekuncen, PasiramanLor, PasiramanKidul, Banjaranyar, Karangkemiri, Kranggan, and Krajan.

\section{b. The rocks type}

The rocks type in the study area is determined based on the reading of the Geological Map of Purwokerto and Tegal Sheets, 1: 100,000 scale and the results of field observations. The results of map reading and field observations in the study area consisted of 5 rock formations. Lava sediment of Slamet Volcano (Qls) is Quaternary (Holocene) age. This formation consists of lava with volcanic rocks composed of andesite-basalt, with a diameter of 10-50 cm, produced by Slamet Tua Volcano, the distribution includes flat areas. Fig.1 shows the Slamet Volcanic sedimentary rock.

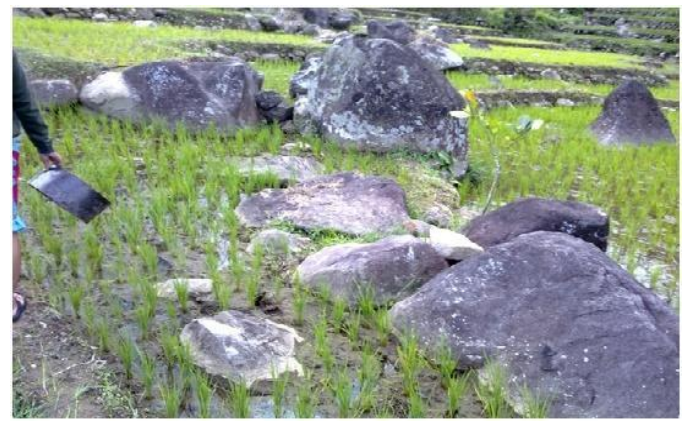

Fig.1. Photograph of Slamet volcanic deposits (Source: Suwarno, 2014).

Slamet Rocks volcano does not decompose (Qvs) Quaternary age (Pleistocene). In this formation, there are volcanic breccia, lava, score and tuff, the distribution of which forms the terrain and hills. Tread formation (Tpt) age Tertiary (Pliocene), consisting of sandstone coarse-grained greenish, calcareous marl, greenish sandstone, calcareous tufa and marl greenery. Tertiary age (Tmph) Formation (middle-end Miocene), consisting of sandstone andesite, tuff, breccia, sand, and napal, inserts sandstones. Tertiary age (Tmr) Formation (Middle Miocene), consisting of marl. Sedimentary materials of Tertiary age from a combination of sand and clay have the highest intensity of avalanches (Luigi Borrelli, et al., 2014). Fig. 2 photos of the following marbles.

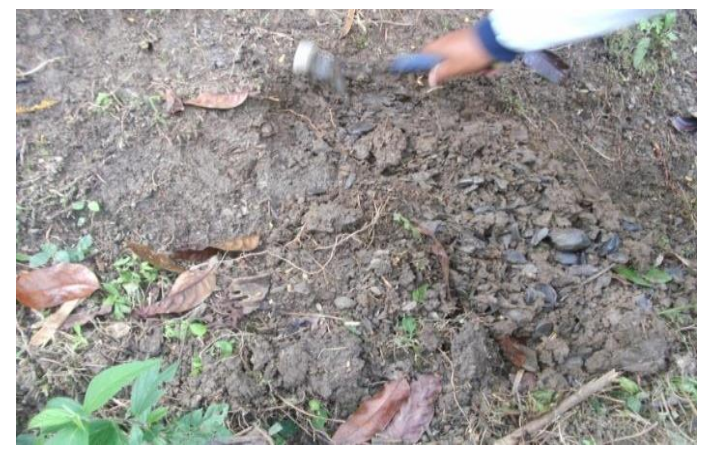

Fig.2. Photograph of marl rocks, (Source: Suwarno, 2014). 
Rocks in the study area are composed of five rock formations and consist of 14 rock types. The fourteen types of rock are 1) Andesite lava, 2) Volcanic breccia, 3) Lava, 4) Skoria, 5) Quaternary Tuff, 6) Greenish sandstone, 7) calcareous marlstone, 8) Greenish marl, 9) Andesite sandstone, 10 ) Tufa gampingan, 11) Tertiary Tufa, 12) Tertiary Breccia, 13) Sandstone, and 14) Marl. Sandstone and clay are one of the causes of high landslide events (Barančoková, et al., 2014).

\section{c. Stratigrafi}

Suwarno (2014) explained that based on observations in the field and reading of the Geological Map of Purwokerto and Tegal Sheets, a scale of 1: 100,000. The results of reading the Geological Map of the stratigraphy in the western part of the sequence from the bottom up are propagation formation (Tmr), Halang (Tmph) formation, and Tread formation (Tpt). In the eastern region, the sequence of stratigraphy from the bottom up is the Creation formation (Tmr), Slamet Volcanic lava deposits (Q1s), and unregulated Slamet Volcanic rocks (Qvs).

The appearance in the field of Tapak formation is seen in Karangkemiri Village and Petahunan Village. In the formation there are 20 landslides, this is caused by the Tread formation located above the Halang formation in the form of sandstone andesite. The andesite sandstone layer becomes a field of landslide slip. The andesite sandstone layer which is part of the Halang formation is seen in Karangkemiri Village. The Halang Formation which is located under the visible Tapak formation in Semedo Village and Cibangkong Village. The Halang Formation in the lower layer is composed of andesite sandstones and above it, there are tuff stones, breccias, sandstones, and marl, therefore in the Halang formation, there are 49 landslides. Andesite sandstones can be seen at the bottom of the Penjalin River Cibangkong Village (Suwarno, 2014).

\section{d. Geological Structure}

Identification of geological structures based on contour patterns, appearance on aerial photographs and results of field observations. Contour patterns in the study area have a straight contour pattern and this meeting indicates a fault structure. Topography is a good guide to estimating fault structures (Barnes \& Lisle, 2004). Topography can be seen in patterns contour, aerial photographs and in the field. The appearance of aerial photographs shows the shape of a long, steep slope. Appearance in the field found six waterfall points in Karangkemiri, Petahuan and Cibangkong Villages. It shows the pattern of straightness and many springs found.

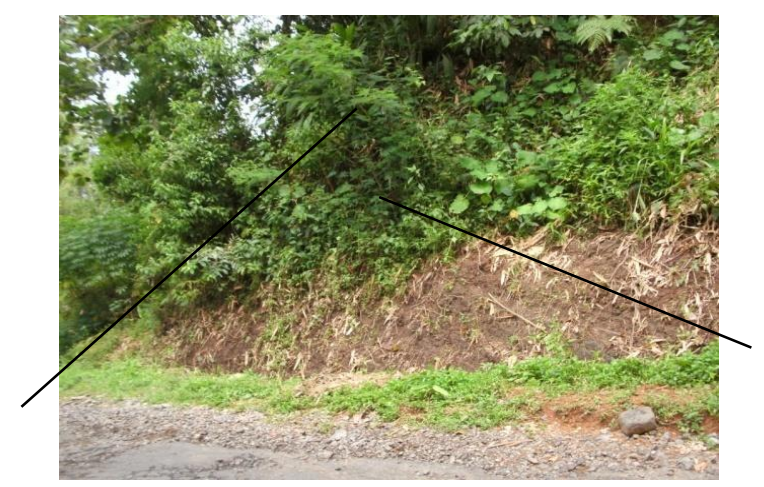

Fig.3. Photograph of the appearance of a fault structure (Source: Suwarno, 2014) 
Outcrops of andesite sandstone are found in several locations with the direction and slope of the layers can be used to characterize the structural origin of the land, and the top layer of rock used for naming units of land. Fig. 3 shows the layers of rock that are truncated and not in line with the slope of this slope can be used as evidence of fault structures. The appearance of the geological structure is like a fault found in Karangdlima Hamlet, Petahuan Village. Barnes \& Lisle (2004) explains that to estimate the fault structure is by knowing the presence of elongated valleys, cracked rock layers that suddenly dropped. The fault is seen in the river valleys that extend along the river channel assault shown in Fig. 4.

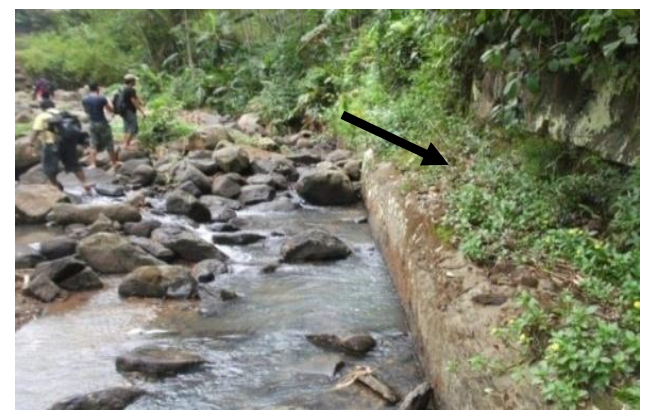

Fig.4. The appearance of a fault (Source: Suwarno, 2014).

The appearance of a sloping rock coating structure that shows the structure of the fold, for example in Klapajejer Hamlet, CibangkongVillage with a slope of $10^{\circ}$ coating and $\mathrm{N} 79^{\circ} \mathrm{E}$ coating direction is shown in Fig. 5.

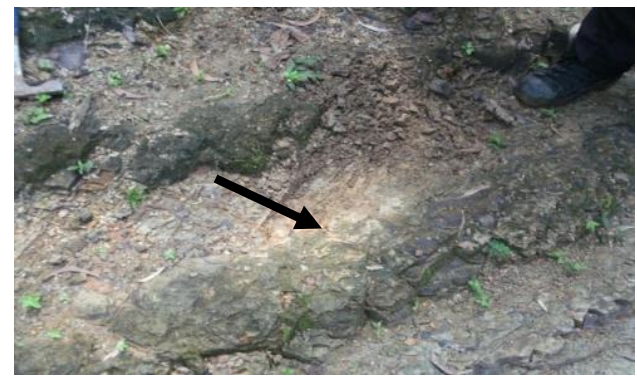

Fig.5. The appearance of a sloping/fold layer on Tuff rocks (Source: Suwarno, 2014)

\section{e. $\quad$ Static Morphostructures}

Static morphostructure can be assessed from the landform actual aspects. The actual landforms reflect static morphostructures in the form of geological structures (HT Verstappen, 1983). The geological structure can be in the form of horizontal structures, tilts, folds, faults, and volumes. Both the synclinal and anticlinal fold structures are found in Petahuan and Cibangkong Villages, fault structures are in Petahuan Village, oblique and structures horizontal are found in Petahuan, Semedo, and Cibangkong Villages, while volcanic structures are found in most areas in DistrictPekuncen.

Based on the geological structure in the study area, there are two landform genesis, namely structural landform units, and volcanic landform units (Suwarno, 2014). Structural origin landform are produced by endogenous processes and layered rock structures. Structural landforms are characterized by changes in the slope of rock layers. At the 
beginning of the rock layers formation is flat, then by the endogenous processes it cause the rock layer to be tilted or shifted. Volcanic origin landform is produced by magma activities, this landform in the study area are located on the slopes below Volcano Slamet. Identification of this volcanic origin is based on the results of field observations and aerial photo interpretation. The results of field observations found that there were materials or rocks originating from the activity of the Slamet Volcano in the form of lava deposits, score rocks, volcanic breccias, and tuffs.

\section{f. Dynamic Morphostructure}

Verstappen (2014) explains that dynamic geomorphology studies the processes and short-term changes in the landforms depicted in dynamic morphostructure. The processes in this case are exogenous processes which consist of weathering, mass movement, erosion, and sedimentation. Weathering of rocks mainly occurs in structural forms. Fig. 6 is an example of weathering of rounded type rocks found in a unit of structural hilly landforms of rocks sandstone, on the slope class IV in Cibangkong Village. Fig. 7 shows the weathering process of rocks in structural landforms units of tufa rocks, on the slope class IV in Semedo Village. The process of weathering that takes place intensively will cause the weathering zone to become thicker. Weathered zones get thicker causing increased slope loads and effecting on landslide.

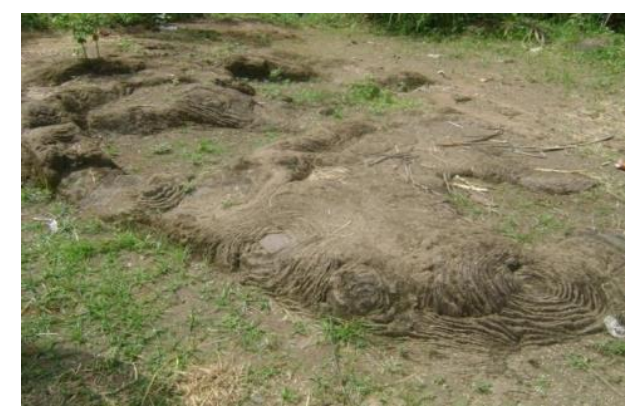

Fig.6. Appearance of sphereoidal weathering onionon sandstone rocks

(Source: Suwarno, 2014)

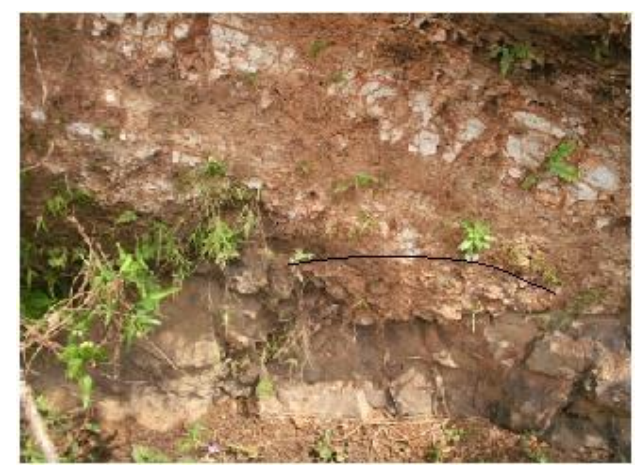

Fig.7. Photo of weathering appearance which is controlled by a system of cracks,

(Source: Suwarno, 2014) 
The process of erosion, especially surface erosion occurs a lot. The slope factor is one reason for surface erosion. Surface erosion is seen in units of landforms structural of tufa rocks, on slope III class in Cibangkong Village (see Fig. 8). These hills look bald and have only been planted with teak plants, and many surface rocks such as gravel and grit are found. Splash erosion takes place and develops to form rill erosion. Worosuprojo (2002) explains that landslides are preceded by rill erosion. Landslide is one of the most common forms of mass movement, 98 landslides were found and in the field survey in this study found the location of 98 new landslides (Suwarno, 2014). Fig.9 is an example of a landslide appearance in the study area.

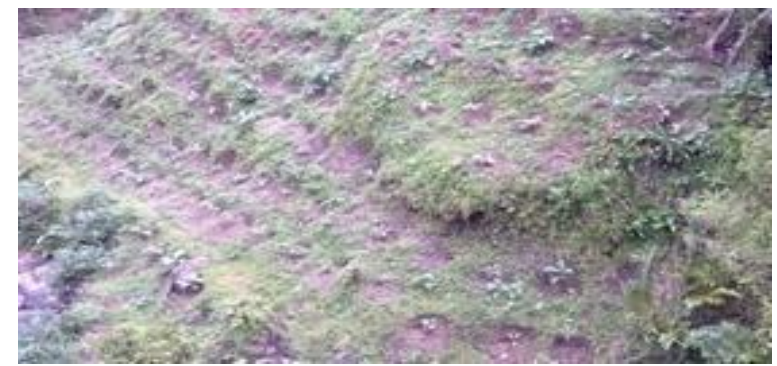

Fig.8. Photos of surface erosion appearance, (Source: Suwarno, 2014)

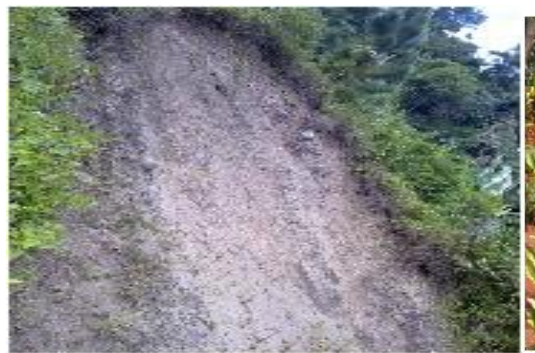

1

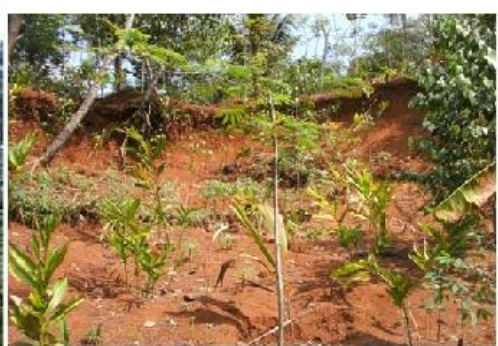

2

Fig.9. Landslide appearance photos in 1.Krajan Village, 2. Village Semedo,

(Source: Suwarno, 2014)

\subsection{The Relationship of Static Morphostructural and Dynamic Morphostructures}

The analysis of relationship of static morphostructure and dynamic morphostructures is carried out by spatial analysis. The spatial analysis to overlay interchanges between maps of landform units with distribution maps of landslide. Static morphostructure is reflected in landforms units of origin structural and volcanic. Structural origin landform are characterized by the presence of geological structures of folds and faults. The fold structure found in the study area is the synclinal fold and the outcrop of rock that is sloping, while the fracture structure is a broken down. The most landslide are found in structural land, this is due to their older age, there are many cracks, and the sloping position is in the direction of the slope (Suwarno, 2018).The results of the overlay arrangement of maps are presented in Figure 10. Based on the analysis, it is illustrated that landslide are related to geological structure patterns. Landslides are clustered on fault structures, folds, and sloping layers, while on the volcanic structure patterned landslides occur. 


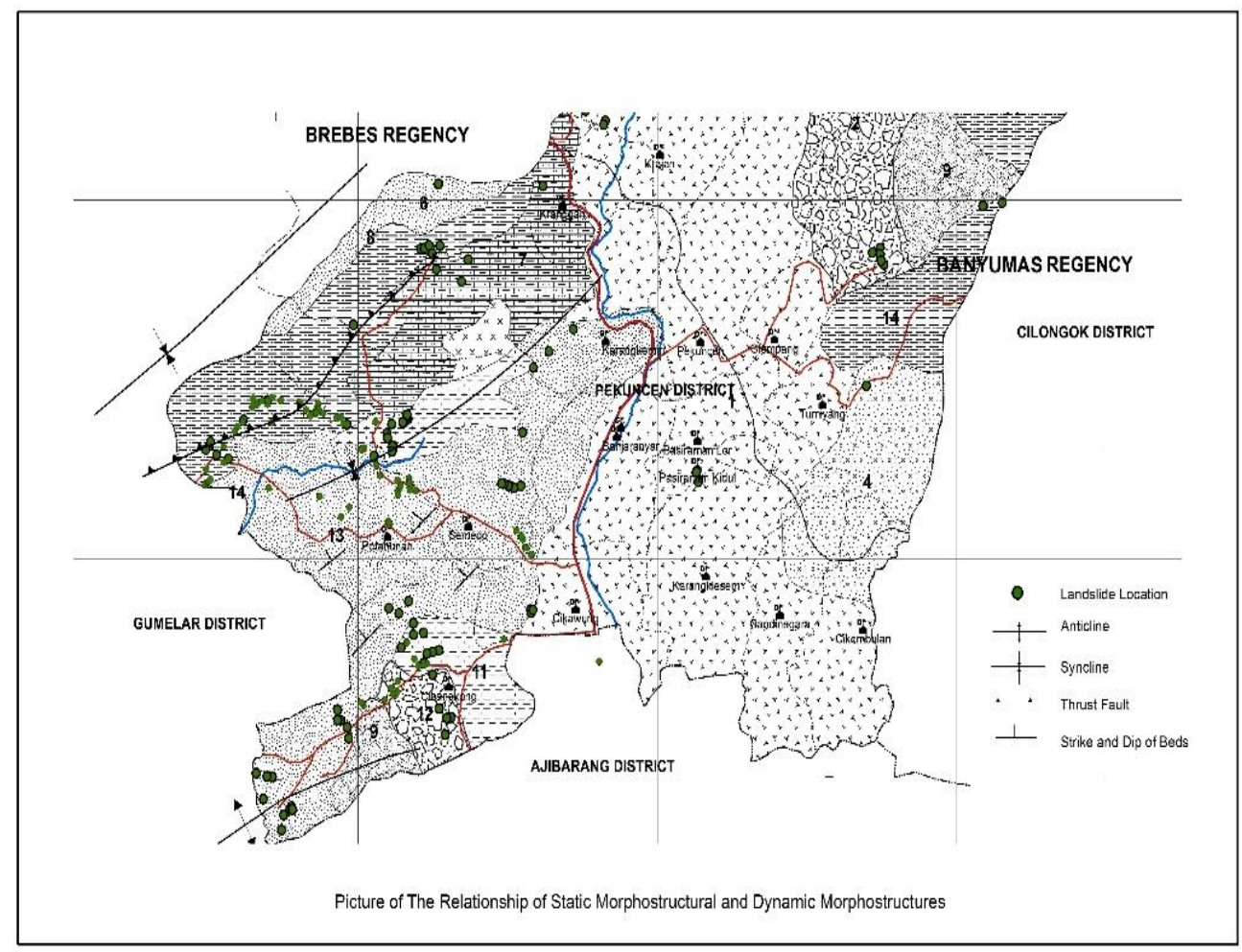

Fig.10. Relationship between Static Morphostructures and Dynamic Morphostructures

(Source: Source: Suwarno, 2014)

\section{CONCLUSION}

Based on the results of the study, it can be concluded that in the study area there were many landslide that could be observed in each unit of land. The geological structure contained is the structure of folds, fractures, and volcano. Many landslides are found in origin structural landforms units which are steep slopes. There is a relationship between landslide and geological structures, in fault structures, folds, and layers sloping with patterns of clustered landslide, while in volcanic structures, the patterns of landslide are spread. In the geological structure of the synclinal folds, many landslides occur in the synclinal valley. In the fault structure, many landslides occur in the fault field. 


\section{R E F E R E N C ES}

Barančoková, M., Kenderessy, P. (2014) Assessment of landslide risk using GIS and statistical methods in the Kysuce region. Ekológia (Bratislava), 33(1), 26-35.

Barnes, J.W., Lisle, R.J. (2004) Basic Geological Mapping. West Sussex PO19 8SQ, England: John Wiley \& Sons Ltd.

Glenn, F.N., David, R.S., John, C.D., Glenn, D.T., Stephen, J.D. (2006) Analysis of Characteristic Topographic Information for Characterizing Landslide Morphology and Activity. Geomorphology, 73, 131-148.

Irimuş, I.-A., Roșca, S., Rus, M.-I., Marian, F.L., Bilaşco, Ș. (2017) Landslide susceptibility assessment in Almas basin by means of the frequency rate and GIS techniques. Geographia Technica, 12(2), 97-109.

Knapen, A., Kitutu, MG, Poesen, J., Breuggelmans, W., J., D., \&Muwanga, A. (2005) Landslides in Densely Populated County at the Footprint of Mount Elgon (Uganda): Characterstics and Causal Factors, Geomorphology, 77, 149-165.

Roback, K., Clark, M.K., West, J.A., Zekko, D., Li, G., Gallen, S.F., Chamlagain, D., Godt, J., (2017) The size, distribution and mobility of landslides Gorkha earthquake, Nepal, Geomorphology, journal homepage: www.elsevier.com/locate/geomorph

Lan, H.X., Zhou, C.H., Wang, L.J., Zang, H.Y., Li, R.H. (2004) Landslide Hazard Spatial Analysis and Prediction Using GIS in The Xiaojiang Watershed, Yunnan, China, Geology Engineering, 76, 109-128.

Borrelli, L., Antronico, L., Gullà, G., Sorriso-Valvo, G.M. (2014) Geology, geomorphology and dynamics of the 15 February 2010 Maierato landslide (Calabria, Italy), Journal of Geomorphology.

Nadim, F., Rodolf, P., Herbert, E., Herbert, K., and Steven, K. (2006) An Introduced Methodology for Estimating Landslide Hazard for Seismic and Rainfall-Induced Landslides in a Geographical Information System Environment, ECI Conference on Geohazards, Lillehammer, Norway.

Pacione, M. (1999) Applied Geography: Principles and Practice. London and New York: Routledge.

Sartohadi, J. (2008) The Landslide Distribution in Loano Sub-District, Purworejo District Central Java Province, Indonesia.Geography Forum, 22(2), 129-144.

Suwarno (2014) Land management models in Longsorlahan Prone Areas in District Pekuncen Banyumas. Gadjah Mada University Yogyakarta.

Suwarno (2018) An Analysis of Landslide Occurrence Distribution and Geomorphological Conditions of River Flow Sub-Watershed in Banyumas Regency. 5th International Conference on Community Development (AMCA 2018). Advances in Social Science, Education and Humanities Research, 231.

Suwarno \& Sutomo (2012) Landslide Mitigation Modeling Based on Geographic Information System Technology in Ajibarang Subdistrict, Banyumas Regency. Purwokerto.

Suwarno, Sutomo \& Aditama M.R. (2019) The analysis of the landslide vulnerability sub watersheds Arus in Banyumas Regency. Geographia Technica, 14(2), 112-119, DOI: 10.21163/GT_2019.142.10

Thapa, BP, and Esaki, T. (2007) GIS-based Quantitative Landslide Hazard Prediction Modeling in Natural Hills, Agra Khola Watershed, Central Nepal, Bulletin of the Department of Geology, Tribhuvan University, Kathmandu, Nepal, 10, 63-70.

Verstappen, H.T. (1983) Applied Geomorphology: Geomorphological Surveys for Environmental Development. Amsterdam: Elsevier.

Verstappen, H.T. (2014) Applied Geomorphology: Geomorphological Survey for Environmental Development. Yogyakarta: Waves.

Worosuprojo (2002) Study of Erosion of Trenches and Landslides with a Geomorphological Approach in the Oyo River Basin of the Special Province of Yogyakarta. Gadjah Mada University Yogyakarta. 